\title{
Potato virus Y (PVY) Y Potato yellow vein virus (PYVV) EN INFECCIONES MIXTAS NO CAUSAN SÍNTOMAS ATÍPICOS EN PLANTAS DE PAPA
}

Potato virus Y (PVY) AND Potato yellow vein virus (PYVV) ON MIXED
INFECTIONS CAUSE NO ATYPICAL SYMPTOMS IN POTATO PLANTS

Jenny Paola Alfaro García • Liliana Franco-Lara'1,2

Observaciones anteriores en cultivos de papa (Solanum tuberosum y Solanum phureja) mostraron síntomas llamados atípicos en este trabajo, que consistían en hojas con manchas irregulares verde oscuro sobre un fondo amarillo intenso, que sugieren la presencia de virus. Estos síntomas no correlacionan con ningún virus descrito para papa en Colombia. En plantas, existen reportes de infecciones virales con dos o más virus que llevan a interacciones como sinergismo o antagonismo. En este trabajo se evaluó la hipótesis de que los síntomas atípicos podrían ser resultado de infecciones mixtas entre PYVV (Potato yellow vein virus) (Crinivirus) y PVY (Potato virus Y) (Potyirus), pues ambos virus son comunes en cultivos de papa en Colombia. Se reportan resultados de RT-PCR (reacción en cadena de la polimerasa mediada por retrotranscripción) para la detección de PYVV y PVY, y de ELISA para PVX, PVS, PVM y PRLV en 57 plantas con y sin síntomas atípicos provenientes de campo. Los resultados no apoyan la hipótesis planteada, pues de 10 plantas con síntomas atípicos evaluadas solo una estaba infectada con los dos virus. Por otro lado, coinfecciones de PVY y PYV se observaron en plantas sin síntomas aparentes (4 plantas de 5 evaluadas) y en plantas con síntomas característicos de PYVV (17 plantas de 37 evaluadas). Del total de 20 plantas evaluadas por ELISA, 18 presentaban infección por PVX aunque no se observaron síntomas asociados a este virus. Ocho de estas plantas, además de PVX estaban infectadas también con PVY y PYV, pero mostraban síntomas de característicos de PYV, lo que sugiere que PVX tampoco correlaciona con los síntomas atípicos. Se sugiere la presencia de un virus no reportado infectando el cultivo de papa en Colombia.

Palabras claves: Coinfección, virus, Potato yellow vein virus, Potato virus Y, sintomatología atípica.

1 Laboratorio de Biotecnología Vegetal, Facultad de Ciencias Básicas y Aplicadas, Universidad Militar Nueva Granada

2 Autor para correspondencia: liliana.franco@unimilitar.edu.co 


\section{ABSTRACT}

Previous observations in potato crops (Solanum tuberosum and Solanum phureja) showed symptoms that in this work are called atypical, and corresponded to leaves with green dark blotches over an intense yellow background, which suggest the presence of a virus. These symptoms do not correlate with virus described for potato crops in Colombia. In plants, there are reports of viral infections with two or more viruses, which may interact leading to synergism or antagonism. In this work, the hypothesis that atypical symptoms may be the result of mixed infections between PYV (Potato yellow vein virus) (Crinivirus) and PVY (Potato virus Y) (Potyvrus) since both virurs are common in Colombian potato crops. This work reports RT-PCR results (Reverse transcriptase- polymerase chain reaction) to detect PYVV and PVY and ELISA tests for PVX, PVS, PVM and PRLV in 57 field plants with and without atypical symptoms. The results do not support the hypothesis, because of 10 plants with atypical symptoms tested just one was infected with both virus. Co-infections of PVY and PYVV were observed in plants without symptoms (4 plants of 5 tested) and in plants with symptoms characteristic of PYV (17 plants of 37 tested). From 20 plants tested by ELISA, 18 showed PVX infection although symptoms associated to this virus were not observed. Eight of these plants were also infected with PVY and PYV, but showed characteristic symptoms of PYVV, which suggest that PVX does not correlate either with atypical symptoms. The presence of a no reported virus infecting potato crops in Colombia is suggested.

Keywords: Coinfection, virus, Potato yellow vein virus, Potato virus $Y$, atypical symptomatology.

\section{INTRODUCCIÓN}

Observaciones anteriores en cultivos de papa Solanum tuberosum y Solanum phureja en Cundinamarca y Nariño mostraron la presencia de síntomas posiblemente causados por virus que no corresponden a síntomas previamente descritos para ningún virus de papa en Colombia. En este trabajo, se llaman "síntomas atípicos" y corresponden a manchas irregulares de color verde oscuro sobre un fondo amarillo intenso (Fig.1 E-I). Una posibilidad es que estos síntomas sean causados por un virus no descrito. Otra alternativa es la existencia de una infección causada por dos o más virus.

En plantas, existen reportes de infecciones virales con dos o más virus que llevan a interacciones como sinergismo o antagonismo (Syller, 2012). El sinergismo se presenta cuando dos o más virus infectan una planta simultáneamente y producen síntomas más severos que la infección de cada virus por aparte; este fenómeno va acompañado de un aumento en el título viral de uno o de ambos virus. En muchos casos se asocia con aumento de las pérdidas económicas también (García-Cano et al. 2006; Pruss et al. 1997; Untiveros et al. 2007).

Un caso particularmente bien estudiado de sinergismo es el que ocurre entre PVY y PVX (Potato virus $X$ ) (Rochow y Ross, 1955), dos virus frecuentes en cultivos de papa en mundo. Cuando estos virus se encuentran coinfectando plantas, se producen síntomas de mosaico severo y pérdidas considerables en la producción mucho mayores a cuando solo uno de los dos virus infecta las plantas (Lawson et al. 1990; Savenkov y Valkonen, 2001). En ensayos realizados 
por Guerrero y Martínez (1980) en la variedad de papa colombiana ICA-Puracé, se observó que infecciones mixtas de PVX y PVY producían síntomas de clorosis, necrosis severa de las nervaduras, marchitez temprana de las plantas, diferentes a los síntomas atípicos.

Por otro lado, los síntomas atípicos podrían ser resultado de infecciones mixtas entre PYV (Potato yellow vein virus) (Crinivirus) y PVY (Potato virus $Y$ ) (Potyvirus), dos virus comunes en cultivos de papa en Colombia (Gil et al. 2011; Franco-Lara et al. 2013; Torres et al. 2014). El virus PYW (Potato yellow vein virus) pertenece al género Crinivirus, de la familia Closteroviridae. Se limita al floema del hospedero y posee un genoma tripartita de $17 \mathrm{kB}$ compuesto de ARN de cadena sencillo, de sentido positivo, con una estructura secundaria conservada en la región 3' no traducible (UTRs) común en el genoma de todos los Crinivirus (Salazar et al. 2000; Livieratos et al. 2004). PYV se presenta en Colombia, Ecuador, Perú y Venezuela y es transmitido de manera semipersistente por la mosca blanca de los invernaderos (Trialeurodes vaporariorum), por injerto y vegetativamente por tubérculos infectados (Salazar et al. 2000). Los síntomas reportados de PYV en papa son: amarillamiento de las venas iniciando de las venas terciarias; el amarillamiento se disemina a las venas secundarias y primarias, y finalmente cubre la lámina foliar parcial o totalmente. Este virus se asocia con importantes pérdidas económicas debido a la disminución de número y tamaño de tubérculos, aunque algunas plantas infectadas pueden permanecer asintomáticas (Salazar et al. 2000; Guzmán et al. 2013). La prevalencia de PYV ha sido estudiada y varía según el departamento de Colombia. En 2008 la prevalencia sintomática de PYV en S. phureja en 19 municipios paperos de Colombia estimada sobre 24,930 plantas era de 0.74 $\% \pm 0.03$ en Cundinamarca, $5.4 \% \pm 12$ en Antioquia y $6.2 \% \pm 0.11$ en Nariño (Franco-Lara et al. 2013). Una estimación más reciente de la prevalencia en papa muestra que el porcentaje de fincas con al menos una planta infectada con el virus era del $89 \%$ en $\mathrm{Na}$ riño, $77 \%$ en Antioquia, $43 \%$ en Cundinamarca y $29 \%$ en Boyacá, lo que sugiere un aumento significativo de este virus en toda Colombia (Torres et al. 2014).

PVY (Potato virus Y) es un Potyvirus, de la familia Potyviridae y posee un genoma de ARN sencillo de sentido positivo de más o menos $10 \mathrm{~Kb}$ (Robaglia et al., 1989). Se reportó por primera vez en 1930, es cosmopolita y se conocen al menos tres cepas: PVYO, PVY-C y el PVY-N (Singh et al. 2008). Muchas especies de la familia Solanaceae son susceptibles a PVY, por ejemplo Solanum spp. y Nicotiana spp. PVY es transmitido por áfidos como Myzus persicae, que es el vector más frecuente, Macrosiphum euphorbiae, Aphis fabae, Myzus certus, Myzus humuly y Rhopalosiphum insertum y otros. También se transmite por injertos, tubérculos y por transmisión mecánica semipersistente (ICTVdB Management, 2006). Los síntomas de PVY reportados en papa son variables pero generalmente incluyen: mosaico moteado, rugosidad de las hojas apicales, bandeado oscuro de las venas en hojas ya desarrolladas, defoliación, algunas veces necrosis apical, enanismo, deformación en hojas y frutos. Además, se reportan pérdidas entre 1080\% (De Bokx and Huntinga, 1981 citado en Walsh et al. 2001). Los síntomas y pérdidas dependen de la variedad de papa, edad de la planta y condiciones ambientales. En muchas plantas infectadas con PVY, el virus solo se manifiesta en la disminución de la productividad (Whitworth et al. 2006). En Colombia se ha registrado la presencia de PVY en cultivos de papa (Sánchez de Luque et al. 1991; Guzmán et al. 2010). En 2009, la prevalencia de Potyvirus en papa estaba entre 56 y $72 \%$ en los departamentos de Boyacá, Cundinamarca, Antioquia y Nariño, y la variantes encontradas correspondieron a PVYN y PVYNTN (Gil et al. 2011). En 2009, la prevalencia de PYV se calculó entre el $56 \%$ y $72 \%$ en los departamentos de Boyacá, Cundinamarca, Antioquia y Nariño, y las variantes encontradas fueron PVYN y PVYNTN (Gil et al. 
2011). La alta prevalencia de PYV y PVY en Cundinamarca permite suponer que en campo se encuentran plantas infectadas con los dos virus. Además, Villamil-Garzón et al. (2014) reportaron plantas de papa en Colombia infectadas simultáneamente con PVY y PYV, sin embargo no describieron los síntomas asociados. Entonces, el objetivo de este estudio era determinar si existe relación de los síntomas atípicos (Figura 1E y F) con la infección simultánea de PYV y PVY en plantas de papa, en Colombia.

\section{MATERIALES Y MÉTODOS}

\section{Ensayo 1}

Se colectaron muestras de hojas de plantas de papa S. phureja (variedad Colombia) y S. tuberosum (ICA única) en el municipio de Subachoque, en dos cultivos (Finca 1: Lat: $4^{\circ} 56^{\prime} 43,397^{\prime \prime} N$, Long: $74^{\circ} 08^{\prime} 11,760^{\prime \prime} W$, altitud 2721,3 m.s.n.m. y Finca 2: Lat: 456'30,019"N, Long: $74^{\circ} 10^{\prime}$ 50,204" W, altitud 2646,6 m.s.n.m) respectivamente. Las muestras se colectaron en marzo de 2014. En el primer cultivo se tomaron al azar 20 muestras y en el segundo 25 muestras y según sus síntomas, plantas se clasificaron en cuatro categorías: síntomas atípicos (Fig. 1E-1I), síntomas de PYV (Fig. 1B y 1C), síntomas de PVY (Fig. 1D) o ausencia de síntomas (Fig. 1A). Las muestras se llevaron al laboratorio de Biotecnología Vegetal del Campus Nueva Granada, Cajicá, Cundinamarca, donde se evaluó la presencia de PVY y PYV. Todas las muestras se evaluaron por RT-PCR con iniciadores específicos para PYV y PVY. Además, un subgrupo de 21 plantas se evaluó por ELISADAS para los virus PVS, PLRV, PVM y PVX.

\section{Ensayo 2}

Las muestras de hojas de papa, S. tuberosum provenían de dos fincas del municipio de El Rosal (Finca 1: Municipio: Rosal, coordenadas: Lat: $4^{\circ} 49^{\prime} 10,77^{\prime \prime} \mathrm{N}$, Long: $74^{\circ} 14^{\prime} 44,369^{\prime \prime}$ W, altitud:
2584,2 m.s.n.m. y Finca 2: Municipio Rosal, coordenadas: Lat: 451'37,44"N, Long: 74 $11^{\prime} 28,875^{\prime \prime} \mathrm{W}$, altitud: 2600 m.s.n.m) y fueron colectadas en mayo de 2014. Se colectaron muestras que presentaban síntomas atípicos (9 plantas), plantas no sintomáticas (1 planta) y plantas con síntomas clásicos de PYV (2 plantas) y no se encontraron plantas con síntomas sugerentes de PVY. Estas muestras se evaluaron por RT-PCR con iniciadores específicos para PVY y PYV en el mismo laboratorio en que se evaluaron las muestras del ensayo 1.

\section{ELISA DAS}

Para la evaluación de los virus PVX, PVM, PVS y PLRV se emplearon kits comerciales (Agdia), siguiendo las instrucciones del fabricante. Se hizo extracción de 0,5g de tejido de hoja en $5 \mathrm{ml}$ de Buffer $(0,1402 \%$ Sulfato de sodio ( $\mathrm{p} / \mathrm{v}), 2 \%$ Polivinilpirrolidona (PVP) MW 24-40,000 (p/v), 0,02\% Azida de sodio $(p / v), 0,2 \%$ Albumina de huevo (Grado II) (p/v), 2\% Tween-20 (p/v), Agua destilada).

Se colocaron $100 \mu \mathrm{l}$ de muestra en cada pozo de la placa de ELISA, se incubó por 2 h en cámara húmeda a temperatura ambiente. Posteriormente, se adicionó la enzima fosfatasa alcalina conjugada con el mismo anticuerpo de captura (dilución 1:100 en Buffer $\mathrm{ECl} 1$ X (2\% Albumina bovina (BSA) (p/v), 2\% PVP (p/v), 0,02\% Azida de Sodio (p/v)) y se reveló con el sustrato PNP (Purine nucleoside phosphorylase) en buffer $1 X(0,01 \%$ Cloruro de Magnesio hexahidrato ( $p / v), 0,02 \%$ Azida de Sodio (p/v) y 9,7\% Dietalonamina $(p / v))$. Entre pasos se lavó 7 veces con PBST 1X (0,8\% Cloruro de Sodio (p/v), 0,115\% fosfato de sodio dibásico (anhidro) ( $p / v), 0,02 \%$ fosfato de potasio monobásico (anhidro) (p/v), 0,02\% Cloruro de potasio (p/v), 0,05\% Tween-20 (p/v)). Una vez adicionado el sustrato se incubó nuevamente por $2 \mathrm{~h}$ a temperatura ambiente en oscuridad y se realizaron mediciones en un lector de ELISA a 410nm. Todos los ensayos incluyeron controles positivos, negativos 
y blancos. Se consideró positiva una muestra cuando el valor de la absorbancia fue 3 veces mayor al valor del control negativo (planta libre de virus).

\section{Extracción de ARN}

A todas las muestras de los ensayos 1 y 2 se les extrajo ARN mediante el método de Trizol (Invitrogen) siguiendo las instrucciones del fabricante, a partir de 0,1g de tejido foliar macerado con nitrógeno líquido. Se adicionó $1 \mathrm{ml}$ de Trizol (Invitrogen) durante 10 minutos a temperatura ambiente, se centrifugó 15 min a 12000 g, y se transfirió la porción acuosa a otro tubo. A la fase acuosa se le adicionó $0,2 \mathrm{ml}$ de cloroformo, se agitó 3 minutos y se centrifugó 12000 g nuevamente. La parte acuosa se transfirió a otro tubo y se añadió $1 \mathrm{ml}$ de isopropanol, incubando a $4^{\circ} \mathrm{C}$ toda la noche. Al día siguiente se centrifugó nuevamente, se desechó el isopropanol y se adicionó $1 \mathrm{ml}$ de etanol absoluto frío, se agitó 5 minutos y se centrifugó 5 min a 7500 g. Se desechó el etanol y se repitieron los tres pasos anteriores con etanol a 70\% frío, se dejó secar el pellet. El ARN se disolvió en $30 \mu \mathrm{l}$ de agua MiliQ por $10 \mathrm{~min}$ a $65^{\circ} \mathrm{C}$. El ARN extraído y se almacenó a $-20^{\circ} \mathrm{C}$.

\section{RT-PCR}

Para la detección de PVY y PYVV, se hicieron amplificaciones de ARN por RT-PCT en dos pasos. En el caso de PVY, se usaron los iniciadores PVYF (5' ACG-TCC-AAA-ATG-AGA-ATG-CC 3') y PVYR (5' TGG-TGT-TCG-TGA-TGT-GAC-CT 3') (Nie y Singh, 2001). Para la retrotranscripción se usaron $2 u l$ de ARN para una reacción de 10ul (1mM dNTPs, 1X buffer de reacción, 10mM DTT, 0,4 $\mu \mathrm{M}$ PVY-R, $8 \mathrm{U}$ MMLV (Invitrogen), 1 U RNAout (Invitrogen) y agua MiliQ). Las reacciones se incubaron $10 \mathrm{~min}$ a $95^{\circ} \mathrm{C}$ seguido por incubación $60 \mathrm{~min}$ a $37^{\circ} \mathrm{C}$. Para la PCR se tomaron 1,6 ul de cDNA en 15 ul con $1 x$ de buffer $\mathrm{NH}_{4}, 2,5 \mathrm{mM}$ de $\mathrm{MgCl}_{2}$ 0,4 uM PVY-R, 0,4 uM PVY-F, $1 \mathrm{mM}$ dNTPS, 0,1 U Biolasa (Bioline) y Agua). El ciclo de amplificación fue: 30 s a $95^{\circ} \mathrm{C}$ a, con 40 ciclos: 30s a $95^{\circ} \mathrm{C}, 45 \mathrm{~s}$ a $53^{\circ} \mathrm{C}, 1 \mathrm{~min}$ a $72^{\circ} \mathrm{C}$ y extensión final: $5 \mathrm{~min}$ a $72^{\circ} \mathrm{C}$ (Nie y Singh, 2001). El producto esperado de la reacción es un amplicón de 480pb. El control positivo se obtuvo de una planta infectada en el cual se había confirmado la presencia de PVY por ELISA. Los productos de PCR se corrieron en gel de agarosa 1\% en TBE 1X (Tris base $89 \mathrm{mM}$, Ácido Bórico 89 mM y EDTA 2 mM (pH: 8)), teñido con bromuro de etidio y observado mediante UV. El tamaño esperado de la banda es de $480 \mathrm{pb}$.

Para PYVV se usaron los iniciadores P3 (5' GACCGCCGACTTGTTGAATT 3') y P4 (5' TTGCTGCATTCTTGAACAGGTAA 3') (López et al. 2006). Para la retrotranscripción se emplearon 4ul de ARN en 10ul, con las mismas concentraciones finales usadas para PVY, con $1 \mathrm{mM}$ de iniciador P4. Las reacciones se incubaron $10 \mathrm{~min}$ a $72^{\circ} \mathrm{C}, 60 \mathrm{~min}$ a $42^{\circ} \mathrm{C}$ y $10 \mathrm{~min}$ a $10^{\circ} \mathrm{C}$. La PCR empleó 2,7 ul de cDNA en una reacción de $16 \mathrm{ul}(0,4 \mathrm{mM}$ dNTPS, 0,4uM P3, 0,4uM P4). El ciclo de amplificación fue: 3 min a $94^{\circ} \mathrm{C}, 35$ ciclos: $1 \mathrm{~min}$ a $94^{\circ} \mathrm{C}, 1 \mathrm{~min}$ a $55^{\circ} \mathrm{C}, 1 \mathrm{~min}$ a $72^{\circ} \mathrm{C}$ y extensión final: $10 \mathrm{~min}$ a $72^{\circ} \mathrm{C}$. El producto esperado de esta reacción es un amplicon de 259 pb. Como control positivo se usó una planta de campo proveniente de Zipaquirá, que presentaba síntomas típicos de PVYY, en la cual se confirmó la presencia del virus por RT-PCR. Las muestras se corrieron en gel de agarosa $1 \%$ en TBE $1 X$, teñido con bromuro de etidio y observado mediante UV. El tamaño esperado de la banda es de 259 pb.

\section{RESULTADOS}

Los síntomas que se asocian a PYVV y a PVY han sido ampliamente descritos. Las plantas infectadas con PYV se caracterizan por la presencia de amarillamiento que inicia en las venas terciarias y secundarias de la parte apical de la hoja y posteriormente se extiende por la lámina foliar, generalmente 
cubriendo la hoja de un color amarillo intenso, donde no se observan las manchas verdes de formas azarosas (Salazar, 1997; Salazar et al. 2000; Guzmán et al. 2013) (Fig. 1B y 1C). Por otro lado, los síntomas de PVY (Fig. 1 D) se asocian con mosaico y rugosidad de las hojas; en muchos casos pasan desapercibidos en el tejido foliar, pero son notorios en los tubérculos (De Bokx y Huntinga, 1981 citado en Walsh et al. 2001). El patrón de pigmentación de las hojas con síntomas atípicos no parece corresponder a PYV o a PVY, pues los síntomas atípicos se observan como manchas de color verde oscuro y formas azarosas sobre un fondo amarillo intenso (Fig. 1E, 1F, 1G, 1H, 1I). Además, la aparición de las manchas amarillas comienza en la base de foliolos y se van extendiendo al resto de la lámina foliar generando los síntomas antes descritos (Figuras $1 \mathrm{G}$ y $1 \mathrm{H}$ ).

Con el fin de determinar si los síntomas atípicos se debían a la presencia simultánea de PYV y PVY en plantas de papa, se realizaron dos ensayos diferentes. En el ensayo 1 se evaluó la presencia de los dos virus en 45 plantas de campo escogidas al azar. No se observaron plantas con síntomas de infección por PVY. En este ensayo, solo una planta presentó síntomas atípicos y fue positiva para PVY, pero no para PYV. De las 45 muestras evaluadas para PVY y PYV (Fig. 2), 20 plantas fueron positivas para los dos virus; de estas 17 tenían síntomas para PYV y tres no mostraban síntomas en las hojas (Tabla 1).

Un subgrupo de 21 de las 45 plantas fueron evaluadas por ELISA. De estas, en 18 se detectó PVX pero las plantas no mostraban mosaicos asociados a este virus. Además, 8 plantas estaban infectadas simultáneamente por PVY, PYW y PVX, pero sus síntomas correspondían a PYW. En las plantas evaluadas por ELISA no se detectaron plantas infectadas con PVM o PVS.

En el ensayo 2, se estudiaron 12 plantas. En nueve de estas, por observación visual se determinó la presencia de síntomas atípicos; cinco de estas muestras fueron positivas para PYV y tres para
PVY, pero solo una presentó coinfección por los dos virus. Por otro lado, en dos plantas con síntomas de PYV se confirmó la presencia de este virus (Fig. 2). Una planta no sintomática fue negativa para PVY y PYV (Tabla 2).
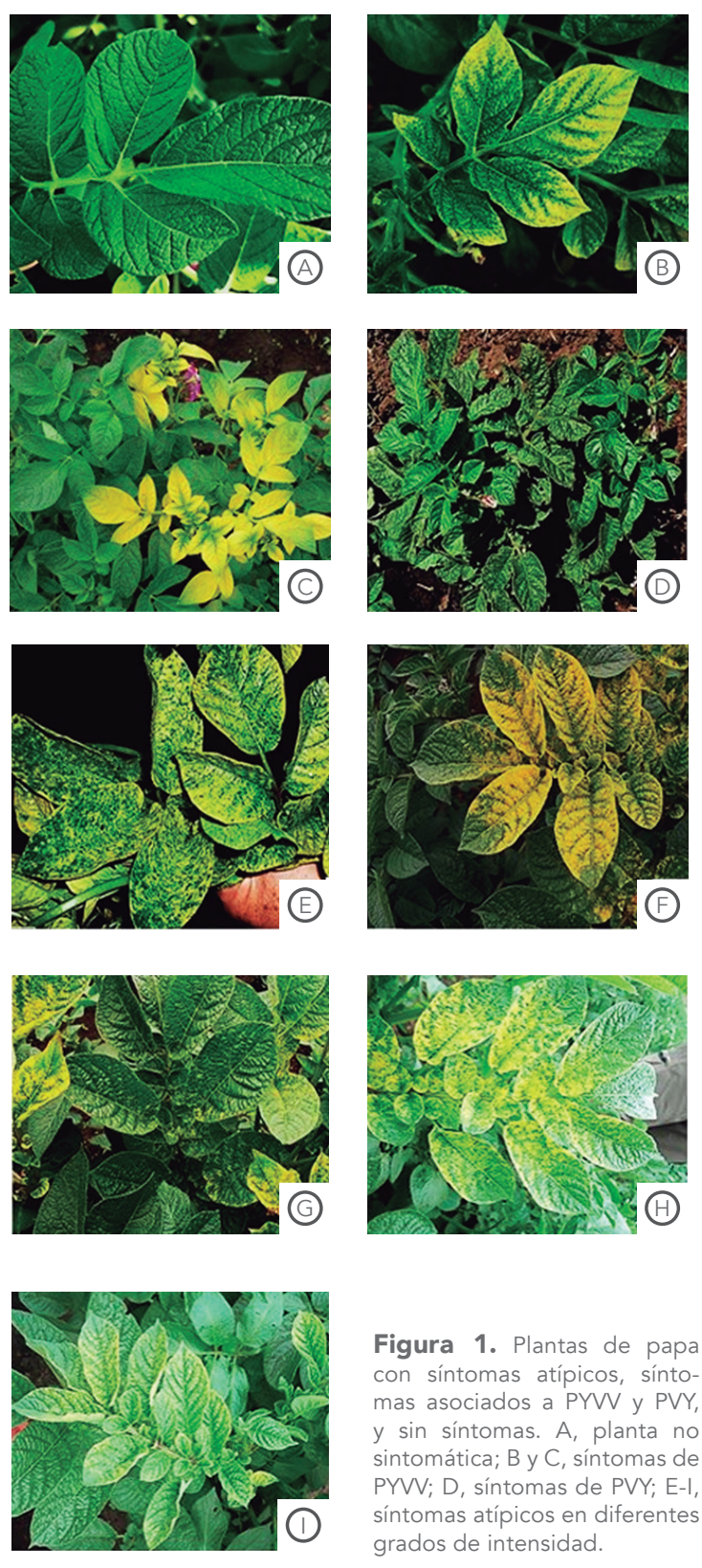

Figura 1. Plantas de papa con síntomas atípicos, síntomas asociados a PYVV y PVY, y sin síntomas. A, planta no sintomática; B y C, síntomas de PYVV; D, síntomas de PVY; E-I, síntomas atípicos en diferentes grados de intensidad. 
Tabla 1. Resultados de RT-PCR y ELISA-DAS del Ensayo 1

\begin{tabular}{|c|c|c|c|c|c|c|c|c|c|}
\hline \multicolumn{5}{|c|}{ RT-PCR } & \multicolumn{5}{|c|}{ ELISA-DAS } \\
\hline Síntomas & $\begin{array}{c}\text { Número } \\
\text { de muestras }\end{array}$ & PVY & PYVV & $\begin{array}{l}\text { PVY + } \\
\text { PYVV }\end{array}$ & PVS & PVX & PLRV & PVM & $\underset{\text { PVY }}{\text { PVY + }}+$ \\
\hline $\begin{array}{l}\text { Sin síntomas } \\
\text { aparentes }\end{array}$ & 9 & $7 / 9$ & $4 / 9$ & $3 / 9$ & $0 / 4$ & $4 / 4$ & $2 / 4$ & $0 / 4$ & $0 / 4$ \\
\hline $\begin{array}{l}\text { Síntomas } \\
\text { de PYVV }\end{array}$ & 35 & $19 / 35$ & $30 / 35$ & $17 / 35$ & $0 / 16$ & $14 / 16$ & $0 / 16$ & $0 / 16$ & $8 / 16$ \\
\hline Síntomas PVY & 0 & & & 0 & & & & & \\
\hline $\begin{array}{l}\text { Síntomas } \\
\text { Atípicos }\end{array}$ & 1 & $1 / 1$ & $0 / 1$ & 0 & $0 / 1$ & $0 / 1$ & $0 / 1$ & $0 / 1$ & $0 / 1$ \\
\hline Total & 45 & $27 / 45$ & $34 / 45$ & $20 / 35$ & $0 / 21$ & $18 / 21$ & $2 / 21$ & $0 / 21$ & $8 / 21$ \\
\hline
\end{tabular}

Los fraccionarios representan el número de muestras positivas/total de muestras evaluadas, por cada categoría de síntomas.

(A)

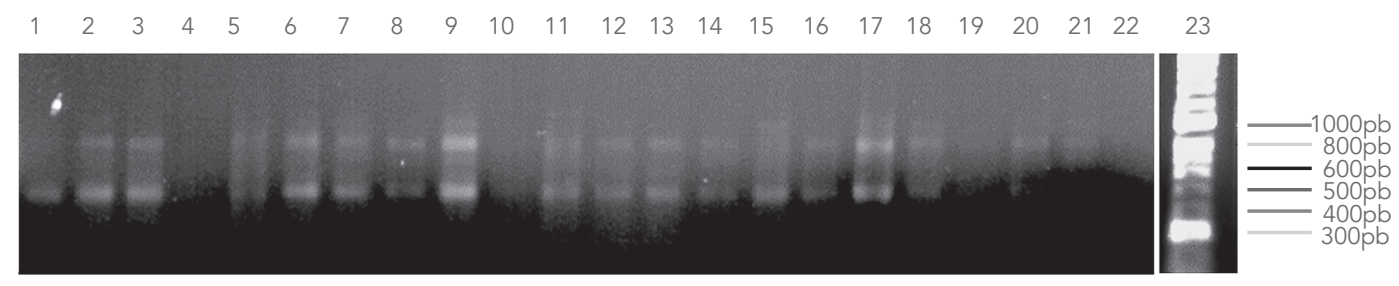

(B)

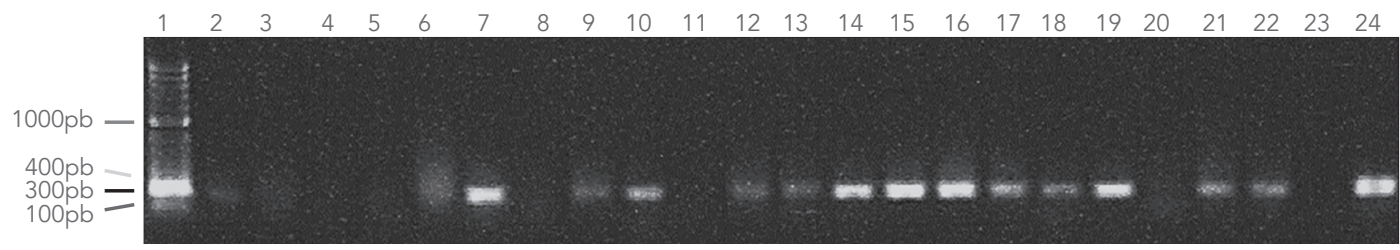

Figura 2. Detección de PVY y PYV por RT-PCR (A) Detección de PVY por RT-PCR Carriles 1 a 20: muestras Finca 1, Carril 20: muestra Finca 1, Carril 21: Finca 2 Carril 22: Control negativo, Carril 23: marcador de peso molecular Hyperladder ${ }^{\mathrm{TM}}$ II (Bioline). (B) Detección de PYVV por RT-PCR. Carril 1: marcador de peso molecular Hypperladder ${ }^{\mathrm{TM}}$ II (Bioline). Carriles 2 a 21 Finca 1, Carril 22: Finca 2, Carril 23: Control negativo, carril 24: Control Positivo PYVV. 
Tabla 2. Resultados de RT-PCR del Ensayo 2

\begin{tabular}{ccccc}
\hline Síntomas & $\begin{array}{c}\text { Número } \\
\text { de muestras }\end{array}$ & PVY & PYVV & PVY + PYVV \\
\hline $\begin{array}{c}\text { Sin síntomas } \\
\text { aparentes }\end{array}$ & 1 & $0 / 1$ & $0 / 1$ & \\
\hline Síntomas de PYV & 2 & - & $2 / 2$ & $1 / 9$ \\
\hline Síntomas Atípicos & 9 & $4 / 9$ & $6 / 9$ & \\
\hline Síntomas PVY & 0 & & & 1 \\
\hline Total & 12 & 4 & 8 & \\
\hline
\end{tabular}

Los fraccionarios representan el número de muestras positivas/total de muestras evaluadas, por cada categoría de síntomas.

\section{DISCUSIÓN}

La presencia de PVY y PYW ha sido reportada para cultivos de papa en Colombia (Sánchez de Luque et al. 1991; Salazar, 1997; Salazar et al. 2000; Gil et al. 2011; Guzmán et al. 2012; Franco-Lara et al. 2013). Además, Villamil-Garzón et al. (2014) reportaron coinfección entre PVY y PYV en Solanum tuberosum en Colombia, mediante secuenciación profunda, sin embargo no asociaron este resultado a síntomas particulares. La secuenciación profunda es una técnica donde se secuencian fragmentos de 21 a 24 nucleótidos de ARN de doble banda, llamados siRNA (small interfering RNAs), los cuales se producen como consecuencia de la activación de un mecanismo de defensa ante la infección de virus ARN y viroides. Estos fragmento se superponen entre sí, de forma que empleando métodos bioinformáticos adecuados es posible reconstruir la secuencia de virus ARN y viroides que infectan una planta, sin necesidad de información previa (Kreuze et al. 2009; Coetzee et al. 2010). Los síntomas atípicos descritos en este trabajo se observan frecuentemente en cultivos de papa con síntomas de infecciones virales, en departamentos como Cundinamarca y $\mathrm{Na}$ riño. Por lo anterior, se evaluó la posibilidad de que coinfecciones entre PVY y PYV fueran la causa de los síntomas atípicos posiblemente debido a una relación sinergística entre los dos virus.

Potyirus y Crinivirus han sido reportados en infecciones sinergísticas, por ejemplo en el caso de Sweet potato chlorotic stunt virus (SPCSV, Crinivirus) y Sweet potato feathery mottle virus (SPFMV, Potyvirus) en Ipomoea batatas L., (Karyeija et al. 2000; Mukasa et al. 2006) y en el caso de Turnip mosaic virus (TuMV, Potyvirus) y Lettuce infectious yellows virus (LIYV, Crinivirus) (Wang et al. 2009). Las interacciones sinergísticas alteran la titulación viral de uno de los virus coinfectantes y agravan los síntomas expresados en el hospedero, generalmente causando un aumento en el porcentaje de pérdidas en cultivos infectados con respecto a un cultivo que solo este infectado con un solo virus (Vance et al.1995). 
Los resultados de este trabajo muestran que los síntomas atípicos no se asocian con la infección simultánea de PVY y PYV. Teniendo en cuenta los resultados de los dos ensayos realizados, plantas coinfectadas con PVY y PYV eran asintomáticas (3 plantas de 10 evaluadas), presentaban síntomas característicos de PYV (17 de 37 plantas evaluadas) y solo en un caso (de 10 evaluadas), una planta coinfectada mostró síntomas atípicos.

Del total de 57 plantas evaluadas, 42 fueron positivas para PYV. De estas, 34 presentaban síntomas característicos del virus, cinco presentaban síntomas atípicos y tres no presentaban síntomas aparentes de virosis. La existencia de plantas infectadas con PYV que no desarrollan síntomas durante su ciclo de vida ha sido reportada anteriormente (Salazar 1997; Salazar et al. 2000; Franco-Lara et al. 2013), pero se desconocen las causas de este fenómeno. La ausencia de síntomas en plantas de papa infectadas con PYV dificulta el diagnóstico del virus y los cálculos de incidencia en campo, además se desconoce el rol de estas plantas en la epidemiología de la enfermedad (Franco-Lara et al. 2013). Por otro lado, se reportan cuatro plantas del ensayo 1 con síntomas severos de PYV, en las cuales no fue posible detectar el virus por RT-PCR. Esto puede deberse a que cuando el tejido manifiesta síntomas severos causados por el virus, la actividad fotosintética del tejido se ve reducida haciéndolo incapaz de mantener la replicación viral; en consecuencia el virus es difícil de detectar (Guzmán et al. 2013).

No se observaron plantas con síntomas de PVY. Los síntomas de PVY son relativos a la cepa del virus, al hospedero (cultivar de papa) y a las condiciones climáticas. Por ejemplo la cepa ordinaria de PVY (PVY') provoca en papa un bandeado severo, rugosidad o enrollamiento de la hoja; la cepa necrótica (PVYn) no causa reacción de hipersensibilidad pero produce un moteado leve y necrosis en las venas en Nicotiana tabacum y $P V Y^{c}$ que produce mosaico leve a severo, rugosidad en la hoja, defoliación y enanismo en algunos cultivares de papa. Además se registran subgrupos en las dos primeras cepas, que se atribuyen a productos de recombinación, PVYNTN y PVYN, los cuales producen síntomas leves en las hojas y/o necrosis en el tubérculo (De Bokx y Huntinga, 1981 citado en Walsh et al. 2001; Piche et al. 2004; Schubert et al. 2007). Según Gil et al. (2011) las cepas PVYN y PVYNTN, se reportan en Colombia; $\mathrm{PVY}^{\mathrm{N}}$ produce síntomas leves en las hojas, como el moteado leve y necrosis en el tubérculo, mientras que PVYNTN produce anillos necróticos en tubérculos. Cuando se produce la enfermedad del anillo necrótico de la papa (PTNRD) causada por PVYNTN se pueden presentar pérdidas en producción hasta del 100\% de perdidas (Schubert et al. 2007), sin embargo en este trabajo no se determinó la presencia de síntomas en los tubérculos.

En el ensayo 1, también se determinó la presencia de otros virus comunes en cultivos de papa en Colombia como PVX, PVS y PLRV (Sánchez de Luque et al. 1991) (Tabla 1), además de PVM, que a pesar de no ser común en cultivos de papa de Colombia, produce síntomas que pueden ser confundidos con los producidos por PVX, PVY y PVS (Ruiz de Galarreta et al. 1998). Del total de 20 plantas evaluadas por ELISA, 18 presentaban infección por PVX aunque no se observaron síntomas asociados a este virus, posiblemente porque el moteado era muy suave y pasó desapercibido durante las observaciones en campo. Ocho de estas plantas, además de PVX estaban infectadas también con PVY y PYV, pero presentaban síntomas de característicos de PYV. Lo anterior sugiere que no existe sinergismo sintomático entre PYV y PVY o PVX. Doce plantas estaban infectadas con PVY y PVX, pero no presentaban el mosaico severo o arrugamiento de las hojas que generalmente se asocia con estos dos virus. El sinergismo entre PVY y PVX es bien conocido y se sabe que causa pérdidas importantes en cultivos de papa (Lawson et al. 1990), entonces es posible que en este caso la 
productividad de las plantas esté considerablemente reducida (Guerrero y Martínez, 1980; Lawson et al. 1990; Savenkov y Valkonen, 2001).

En conclusión, se rechaza la hipótesis planteada inicialmente, es decir que los síntomas atípicos no se deben a la coinfección por PVY y PYV, lo que concuerda con lo reportado por Villamil-Garzón et al. (2014) en donde se descarta la existencia de sinergismo entre PVY y PYV en plantas de papa y se propone una relación neutral entre ellos. Por otro lado, los síntomas atípicos observados podrían corresponder a síntomas producidos por un virus no reportado para Colombia. Los virus causan síntomas muy diversos en las plantas y que su expresión puede confundirse con el efecto de desbalances nutricionales en plantas, aunque generalmente los desbalances nutricionales se observan de forma generalizada en el cultivo, y no en unas pocas plantas como en este caso. Los síntomas más obvios en plantas se observan en las hojas aunque otros órganos también se ven afectados. En hojas, se pueden detectar lesiones cloróticas (cuando hay pérdida de actividad fotosintética), necróticas (muerte celular) o las manchas en forma de anillo. También se observan parches decolorados, mosaicos, moteados, rallados, variegaciones, amarillamiento de las venas o de las regiones intervenales entre otros. Todos estos síntomas tienen en común que se observan como regiones decoloradas o amarillas de diversas formas que contrastan con regiones verdes del color normal de las hojas sanas, algunas veces con bordes bien definidos y otras veces con bordes difusos (Agrios, 1997; Matthews, 1980). Los síntomas atípicos observados en este trabajo, corresponden a secciones amarillas sobre un fondo verde oscuro con forma de moteado severo, pero se requieren evidencias adicionales para determinar su etiología.

A pesar del pequeño número de muestras evaluadas en este trabajo, se plantean interrogantes acerca de los síntomas causados por virus en los cultivares colombianos y las posibles interacciones que ocurren entre ellos. Además, sugieren la existencia de un virus diferente a PVX, PVY, PVS, PLRV, PVM y PYV que sería el agente etiológico de los síntomas atípicos. En Colombia hay estadísticas muy limitadas acerca de la prevalencia de virus en cultivos de papa evaluados por ELISA o por RT$P C R$, pero estos resultados sugieren que muchos virus pueden pasar desapercibidos en la evaluación visual por síntomas y que deben existir otros virus no reportados a la fecha que puede afectar la producción de papa en el país.

\section{AGRADECIMIENTOS}

A la Dra. Mónica Guzmán del IBUN por su apoyo en la realización del trabajo. A la Universidad Militar Nueva Granada por la financiación a través del proyecto CIAS 935.

\section{REFERENCIAS}

1. Agrios GN. 1997. Plant Pathology. Academic Press. PP 489-490.

2. Coetzee B, Freeborough MJ, Maree HJ, Celton JM, Rees DJ y Burger, JT. 2010. Deep sequencing analysis of viruses infecting grapevines: virome of a vineyard, Virology 400: 157-163.

3. De Bokx JA y Huttinga H. 1981. Potato Virus Y. CMI/AAB Descriptions of Plant Viruses. No. 242 (No. 37 revised). Commonwealth Mycol. Inst./ Assoc. Applied Biol., Kew, Surray, England.

4. Franco-Lara L, Rodríguez Dy Guzmán M. 2013. Determination of the prevalence of potato yellow vein virus (PYW) in crops of Solanum phureja in three states of Colombia. American Journal of Potato Research, 90: 324-330. 
5. García-Cano E, Renato OE, Fernández-Muñoz R y Moriones E, 2006. Synergistic Interaction between Tomato chlorosis virus and Tomato spotted wilt virus Results in Breakdown of Resistance in Tomato. Phytopathology, 96:1263-1269.

6. Gil JF, Cotes JM y Marín M. 2011. Incidencia de Potyvirus y Caracterización molecular de PVY en Regiones Productoras de papa (Solanum tuberosum L.) de Colombia. Revista Colombiana de Biotecnología, 13: 85-93.

7. Guerrero OA y Martinez G. 1980. Evaluación de pérdidas ocasionadas en la variedad de papa ICA-Puracé, por los virus Potato virus $X$, Potato virus $Y$ y Potato Leafroll virus. Fitopatología Colombiana, 9:33-40.

8. Guzmán M. Franco-Lara L, Rodríguez P, Vargas L y Fierro JE. 2012. Yield Losses in Solanum tuberosum Group Phureja Cultivar Criolla Colombia in Plants with Symptoms of PYW in Field Trials. American Journal of Potato Research, 89: 438-447.

9. Guzmán-Barney M, Hernández AK y FrancoLara L. 2013. Tracking Foliar Symptoms Caused by Tuber-Borne Potato Yellow Vein Virus (PYVV) in Solanum Phureja (Juz et Buk) Cultivar "CrioIla Colombia". American Journal of Potato Research, 90: 284-293.

10. Guzmán M, Román $V$, Franco-Lara L y Rodríguez P. 2010. Presencia de cuatro virus en algunas accesiones de la Colección Central Colombiana de papa mantenida en campo. Agronomía Colombiana, 28: 225-233.

11. ICTVdB Management (2006). Potato virus Y. En: ICTVdB - The Universal Virus Database, version 4. Büchen-Osmond, C. (Ed), Columbia University, New York, USA http://ictvdb.bio-mirror.cn/ICTVdB/00.057.0.01.001.htm, Consulta Septiembre de 2014.

12. Karyeija RF, Kreuze JF y Valkonen JPT. 2000. Synergistic interactions of a Potyvirus and a phloem-limited crinivirus in sweet potato plants. Virology, 269: 26-36.
13. Kreuze JF, Pérez A, Untiveros M, Quispe $D$, Fuentes S, Barker I y Simon R. 2009. Complete viral genome sequence and discovery of novel viruses by deep sequencing of small RNAs: A generic method for diagnosis, discovery and sequencing of viruses. Virology, 388:1-7.

14. Lawson C, Kaniewski W, Haley L, Rozman R, Newell C, Sanders P y Tumer NE. 1990. Engineering Resistance to Mixed Virus Infection in a Commercial Potato Cultivar: Resistance to Potato Virus $X$ and Potato Virus $Y$ in Transgenic Russet Burbank. Biotechnology, 8: 127-134.

15. Livieratos IC, Eliasco E, Müller G, Olsthoorn RCL, Salazar LF, Pleij CWA. y RHA Coutts. 2004. Analysis of the RNA of Potato yellow vein virus: evidence for a tripartite genome and conserved 3 '-terminal structures among members of genus Crinivirus. Journal of General Virology, 85: 2065-2075.

16. López R, Ascensio R, Guzmán MM y Booham N. 2006. Developmental of Real-Time and Conventional PCR assays for the detection of Potato Yellow Vein Virus (PYV). Journal of Virological Methods, 136: 24-29.

17. Matthews REF. Plant Virology. Third Edition PP 23-50.

18. Mukasa SB, Rubaihayo PR y Valkonen JPT. 2006. Interactions between a Crinivirus, an Ipomovirus and a Potyvirus in coinfection sweetpotato plants. Plant Pathology, 55: 458-467.

19. Nie $X$ y Singh RP. 2001. A novel usage of random primers for multiplex RT-PCR detection of virus and viroid in aphids, leaves, and tubers. Journal of Virological Methods, 91: 37-49.

20. Piche LM, SinghRP, Nie $X$ y Gudmestad NC. 2004. Diversity among Potato virus $Y$ isolates obtained from potatoes grown in the United States. Phytopathology, 94: 1368-1375.

21. Pruss G, Ge X, Ming S, Carrington J.C y Bowman V. 1997. Plant Viral Synergism: The Potyviral Genome Encodes a Broad-Range 
Pathogenicity Enhancer That Transactivates Replication of Heterologous Viruses. The Plant Cell, 9:859-868.

22. Robaglia C, Durand-Tardif M, Tronchet M, Boudazin G, Astier-Manifacier S y Casse-Delbart, F. 1989. Nucleotide sequence of Potato Virus $Y$ (N Strain) genomic RNA. Journal of Virology, 70: 935-947.

23. Rochow WF y Ross F. (1955). Virus multiplication in plants doubly infected by potato viruses $X$ and $Y$. Virology, 1:10-27.

24. Ruiz de Galarreta JI, Carrasco A, Salazar A, Barrena I, Iturritxa E, Marquinez R, Legorburu FJ y Ritter E. 1998. Wild Solanum species as resistance sources against different pathogens of potato. Potato research, 41:57-68.

25. Salazar LF. 1997. La Enfermedad del Amarillamiento de las Venas de la Papa. Evidencia de la presencia de un virus inusual. Agroenfoque, 85: 24-26.

26. Salazar LF, Müller G, Querci M. Zapata y Owens RA. 2000. Potato Yellow Vein: its host range, distribution in South America and identification as a Crinivirus transmitted by Trialeurodes vaporariorum. Annals of Applied Biology, 137: 007-019.

27. Sánchez de Luque C, Corzo P y Pérez OA.1991. Incidencia de Virus de Papa y su Efecto sobre Rendimiento en Tres Zonas Agroecológicas de Colombia. Revista Latinoamericana de la Papa, 4: 36-51.

28. Savenkov El y Valkonen JP. 2001. Potyviral helper-component proteinase expressed in transgenic plants enhances titers of Potato leaf roll virus but does not alleviate its phloem limitation. Virology, 283: 285-93.

29. Schubert J, Fomitcheva $V$ y Sztangret-Wísniewskab J. 2007. Differentiation of Potato virus $Y$ strains using improved sets of diagnostic PCR-primers. Journal of Virological Methods, 140: 66-74.

30. Singh RP, Valkonen JPT, Gray SM, Boonham N, Jones RAC, Kerlan Cy Schubert J. 2008. The naming of Potato virus $Y$ strains infecting potato. Archives of Virology, 153: 1-13.

31. Syller J. 2012. Facilitative and antagonistic interactions between plant viruses in mixed infections. Molecular Plant Pathology, 13: 204-216.

32. Torres D, Hernández A, Martínez J, y Pérez $O$. 2014. Evaluación de algunos factores asociados a la presencia del virus del amarillamiento de las nervaduras de la hoja de la papa (PYVV) en los cuatro principales departamentos productores de Colombia. XXVI Congreso Latinoamericano de la papa (Memorias).

33. Untiveros M, Fuentes S y Salazar LF. 2007. Synergistic interaction of Sweet potato chlorotic stunt virus (Crinivirus) with carla-, cucumo-, ipomo-, and potyviruses infecting sweet potato. Plant Dis, 91:669-676.

34. Vance VB, Berger PH, Carrington JC, Hunt AH y Chi XM. 1995. 5' Proximal Potyviral Sequences Mediate Potato Virus X/Potyviral Synergistic Disease in Transgenic Tobacco. Virology, 206: 583-590.

35. Villamil-Garzón A, Cuellar WJ y Guzmán M. 2014. Natural co-infection of Solanum tuberosum crops by Potato yellow vein virus and Potyvirus in Colombia. Agronomía Colombiana, 32: 213-223.

36. Walsh K, North J, Barker I y Boonham N. 2001. Detection of different strains of Potato virus $Y$ and their mixed infections using competitive fluorescent RT-PCR. Journal of Virological Methods, 91: 167-173.

37. Wang J, Turina M, Medina V y Falk BW. 2009. Synergistic interaction between the Potyvirus, Turnip mosaic virus and the Crinivirus, Lettuce infectious yellows virus in plants and protoplasts. Virus Research, 144: 163-170.

38. Whitworth JL, Nolte P, Mclntosh C y Davidson R. 2006. Effect of Potato virus $Y$ on yield of three potato cultivars grown under different nitrogen levels. Plant Disease, 90:73-76. 